\title{
Okul Öncesi Öğretmenlerinin ve Öğretmen Adaylarının Toplama ve Çıkarmaya İlişkin Sözel Problem Kurma Becerileri $^{1}$
}

\begin{tabular}{lccc}
\hline MAKALE TÜRÜ & Başvuru Tarihi & Kabul Tarihi & Yayın Tarihi \\
Araştırma Makalesi & 18.02 .2019 & 25.10 .2019 & 01.04 .2020 \\
\hline
\end{tabular}

Yaşare Aktaş Arnas (iD) ${ }^{2}$ ve Kamuran Tarım

Çukurova Üniversitesi

$\ddot{\mathrm{O} z}$

$\mathrm{Bu}$ araștırmanın amacı, okul öncesi öğretmenlerinin ve öğretmen adaylarının sözel problem kurma becerilerini incelemektir. Araştırmanın verileri, Adana'da bir devlet üniversitesinde, 2016-2017 öğretim yılında Okul Öncesi Öğretmenliği Anabilim Dalında öğrenim görmekte olan 179 üçüncü ve dördüncü sınıf öğrencisi ile Adana'da İl Milli Eğitim Müdürlüğüne bağlı okul öncesi eğitim kurumlarında görev yapan 93 okul öncesi öğretmeninden elde edilmiştir. Araştırmanın verileri araştırıcılar tarafindan oluşturulan Sözel Problem Kurma Formu kullanılarak toplanmıştır. Verilerin çözümlenmesinde frekans ve yüzde teknikleri kullanılmıștır. Araștırma sonucunda, öğretmenlerin ve öğretmen adaylarının bazı sözel problem türlerini doğru kurarken bazılarını kuramadıkları görülmüştür. Hem öğretmenlerin hem de öğretmen adaylarının çoğunlukla birleştirme / sonuç bilinmeyenli; birleştirme / değişim bilinmeyenli; ayırma / sonuç bilinmeyenli; ayırma / değişim bilinmeyenli problem türlerini kurmada büyük oranda başarılı oldukları belirlenmiştir. Bununla birlikte hem öğretmenlerin hem de öğretmen adaylarının parça parça bütün-bütün bilinmeyenli; parça parça bütün-parça bilinmeyenli; karşılaştırma küçük çoğunluğu bilinmeyenli; karşılaştırma fark bilinmeyenli problem türlerini kurmada çok az başarılı oldukları görülmüștür. Bununla birlikte karșılaștırma büyük çoğunluğu bilinmeyenli problem türünü kurmada hiç başarılı olamadıkları bulunmuştur.

Anahtar sözcükler: Matematik eğitimi, okul öncesi eğitim, okul öncesi öğretmeni, öğretmen adayı, problem kurma, sözel problemler.

${ }^{1} \mathrm{Bu}$ makale Çukurova Üniversitesi Bilimsel Araştırma Birimi tarafından desteklenen SBA 201810333 numaralı projeden üretilmistir.

${ }^{2}$ Sorumlu Yazar: Prof. Dr., Eğitim Fakültesi, Temel Eğitim Bölümü, Okul Öncesi Eğitimi Anabilim Dalı, E-posta: yasare@cu.edu.tr, https://orcid.org/0000-0002-0738-9325

${ }^{3}$ Prof. Dr., Eğitim Fakültesi, Matematik ve Fen Bilgisi Eğitimi Bölümü, Matematik Eğitimi Anabilim Dalı, E-posta: gkamuran@cu.edu.tr, https://orcid.org/0000-0002-2048-5207 


\section{Okul Öncesi Dönemde Matematik Eğitimi}

Pekçok okul öncesi öğretmeni, matematik eğitiminin küçük çocuklar için çok uygun olmadığına inanmakta ya da küçük yaştaki çocuklara matematik öğretme konusunda endişe duymaktadırlar (Baroody, Lai ve Mix, 2002). Okul öncesi öğretmenleri için matematik, küçük çocuklara öğretilmesi için zor bir konudur. Aynı zamanda okul öncesi öğretmenleri, çoğu zaman matematiğin özellikle akıl yürütme, problem çözme, iletişim becerileri gibi temel süreç becerileri ile ilişkili olduğundan habersizdirler. Bu nedenle sayma ve basit aritmetik işlemleri dışında matematik öğretimini genellikle göz ardı etmektedirler (Copley, 2004). Ancak son yıllarda, küçük çocuklara matematik öğretmeye ilişkin öğretmen tutumlarında çarpıcı bir şekilde değişim olmuştur. Bu değişimdeki en önemli etmenlerden birisi Amerikan Ulusal Matematik Öğretmenleri Konseyi'nin (National Council of Teachers of Mathematics-NCTM, 2000), çocukların matematiksel gelişimi için temellerin en erken yıllarda atılması gerektiği sonucuna varmış olması ve Amerikan Ulusal Kü̧̈ük Çocukların Eğitimi Derneği (National Association for the Education of Young Children-NAEYC) ile birlikte 3-6 yaş çocuklar için yüksek kaliteli, gelişimsel olarak uygun matematik eğitimi çok önemlidir düşüncesinde birleşmiş olmalarıdır (akt., Baroody, Lai ve Mix, 2002).

Yapılan çalışmalar da okul öncesi öğretmenlerinin küçük çocuklara matematik öğretmekle ilgili düşüncelerinin aksine çocukların erken yaşlarda pek çok matematik kavramını öğrenebileceklerini göstermektedir (Aunola, Leskinen, Lerkkanen ve Numi, 2001; Resnick, 1989). Özellikle çocukların erken yaşlarda karşı karşıya kaldıkları matematik deneyimleri ile daha sonraki matematik başarıları arasında ilişkiler olduğunu gösteren pek çok çalışma mevcuttur (Clements ve Samara, 2013; Duncan ve diğ., 2007; Jordan, Kaplan, Locuniak ve Ramineni, 2007; Jordan, Ramineni ve Locuniak, 2009; La Paro ve Pianta, 2000; Stevenson ve Newman, 1986). Örneğin, Duncan ve diğ. (2007) yaptıkları bir meta analizi çalışmasında, okul öncesi dönemdeki erken matematik becerilerinin daha sonraki yıllardaki matematik başarısında önemli bir gösterge olduğunu belirlemiştir. Çünkü okul öncesi dönemde çocukların matematik deneyimleri, onların matematiği kavrama ve dolayısı ile bilişsel gelişimlerinin de temelini oluşturmaktadır. Erken dönemdeki bu gelişim, doğal olarak ileriki yıllardaki matematik başarısının da bir yordayıcısı olmaktadır.

Öyle ki okul öncesi yıllarda çocuklar yapılandırılmış matematik etkinlikleri dışında informal yollarla bir çok matematiksel bilgiyi öğrenebilmektedirler (Clements ve Samara, 2013; Gürgah Oğul ve Aktaş-Arnas, 2016; Schoenfeld, 1988; Seo ve Ginsburg, 2004). Bu nedenle çocukların matematik bilgilerinin pek çoğu onların doğal öğrenme deneyimlerinin bir sonucudur. Örneğin, Vygotsky'nin çalışmalarını önemseyen Gelman ve Gallistel (1978), bir çocuğun aritmetik becerisinin çocuğun doğal matematik deneyimlerine dayandığını vurgulamışlardır. Eğer öğretmenler çocuklara zengin uyarıcı bir çevre sunar ve uygun öğrenmelere firsat verilirlerse, çocuklar matematiğin çok geniş ve karmaşık bilgilerini informal yollarla da öğrenebilirler (Clements ve Samara, 2013). 
Ancak okul öncesi yıllarda çocuklara matematik öğretiminin temel amacı sadece çocuklara matematik kavram ve konularının öğretilmesi değildir. Öğretmenlerin temel amaçlarından birisi çocuklara matematiksel düşünme yollarını öğretmek olmalıdır (Kamii, Miyakawa ve Kato, 2004). Bu noktada okul öncesi öğretmenlerinin yanıt bulmaları gereken en önemli soru Hangi matematik kavramlarını, hangi yollarla öğretmeliyim? olmalıdır.

Alanyazın incelendiğinde Amerikan Ulusal Matamatik Öğretmenleri Konseyi (NCTM) gibi alanında önde gelen kuruluşlar okul öncesinden başlayarak çocuklara öğretilmesi gereken konuların;

- Sayılar ve işlemler

- Geometri

- Ölçme

- Cebir-Örüntü

- Veri analizi ve olasılık konularını kapsaması gerektiğini vurgulamaktadır (NCTM, 2000).

Milli Eğitim Bakanlığı (MEB) Okul Öncesi Eğitim Programı incelendiğinde de okul öncesi çocuklara kazandırılması gereken beceriler arasında basit toplama ve çıkarma işlemlerini yapması belirtilmiştir (MEB, 2013).

\section{Okul Öncesi Çocuklara Toplama ve Çıkarma İşleminin Öğretimi}

Temelde toplama ve çıkarma işlemlerinin öğretimi, sayma becerisinin gelişimi ile paralel ilerleyen bir süreçtir. Bu iki kavramın öğretimi birbiri ile doğrudan ilişkilidir. Ancak çocuklarla toplama ve çıkarmaya ilişkin işlemlerin öğretimine başlanılmadan önce çocukların sayma, rakamları tanıma-yazma-söyleme, sıralama, sınıflandırma, sembolleri tanıma ve anlamını bilme ve sayı korunumunu kazanmış olması gerekmektedir (Aktaş-Arnas, 2012).

Piaget, okul öncesi dönemdeki çocukların toplama ve çıkarma işlemlerini yapabilmeleri için bazı sınırlılıklarının olduğunu belirtmektedir. Piaget, çocukların toplama ve çıkarma işlemlerini kavrayabilmeleri için sayı korunumunu kazanmış olmaları ve parça bütün ilişkisini anlamaları gerektiğini vurgulamaktadır. Piaget çocuklar parçayı bütüne dahil edemediklerinde problemi çözmekte başarısız olacaklarını vurgulamaktadır (Altun, 2000). Ancak son yıllarda yapılan çalışmalar, okul öncesi dönemdeki çocukların sayı kavramını kazanma ve parça bütün ilişkisini anlamada başarılı olduklarını ortaya koymaktadır (Starkey, 1992). Özellikle çocuklara sunulan toplama ve çıkarma işlemleri sayısal sembollerle değil sözel problemlere dönüştürülerek sorulduğunda çocukların işlemi daha kolay kavradıkları alanyazında da vurgulanmaktadır (Tarım ve Deretarla-Gül, 2003).

Bununla birlikte sözel problem çözme becerisi çocuklarda biranda gelişmez. Bu yeteneğin gelişimi yavaş ilerleyen bir süreç olup süreklilik gerektirmektedir (Van de Walle, 1994). Bu nedenle çocukların sözel problem çözme becerilerinin gelişmesi için öğretmenlerin programda okul öncesi dönemden başlayarak bu becerilere yönelik 
öğrenme öğretme etkinliklerine yer verilmesi önerilmektedir (Tarım, 2017; Van De Walle, Karp ve Bay-Williams, 2016). Bu anlamda etkinliklerin uygulayıcısı olan öğretmenlerin ve öğretmen adaylarının sözel problemlerle ilgili hem eğitim bilimsel hem alan bilgilerinin önemli olduğu yadsınamaz. Bir başka deyişle öğretmenlerin ve öğretmen adaylarının sözel problemlerle ilgili alan bilgilerinin ve bunları öğrenmeöğretme ortamlarına nasıl taşıyacakları ile ilgili eğitim bilimsel bilgilerinin yeterliği önemlidir.

\section{Sözel Problem Türleri}

Alanyazında toplama ve çıarmayla ilgli problemler farklı sinıflandirılabilmektedir. Burada Van De Walle, Karp ve Bay-Williams (2016) tarafından yapılan toplama ve çıkarma işlemlerine yönelik sözel problemlerin sınıflandırması esas alınmıştır. Bu sınıflamaya göre toplama ve çıkarmayla ilgili sözel problemler birleştirme, ayırma, parça-parça-bütün, karşılaştırma problemleri şeklinde isimlendirilmiştir. Araştırmacılar (Haylock ve Cockburn, 2004; Sarama ve Clements, 2009) çocukların sözel problemleri çözebilme becerilerinin, bu problem türlerine ve problemlerde yer alan bilinmeyen değişkenine göre farklılık gösterebileceğini belirtmiştir.

Van De Walle, Karp ve Bay-Williams (2016) toplama ve çıkarma işlemlerine ilişkin sözel problem türlerini, birleştirme, ayırma, parça-parça-bütün, karşılaştırma problemleri olmak üzere bilinmeyen türüne göre 11 alt kategoriye ayırmıştır (Tablo $1)$.

Tablo 1

Toplama ve Çıkarmaya Yönelik Sözel Problem Türlerinin Sınıflandırılması

\begin{tabular}{|c|c|c|}
\hline \multicolumn{3}{|c|}{ Birleştirme } \\
\hline Sonuç bilinmeyenli & Değișim bilinmeyenli & Başlangıç bilinmeyenli \\
\hline $\begin{array}{l}\text { Deniz'in elinde } 3 \text { balon vard1. } \\
\text { İki tane de Berke verdi. } \\
\text { Deniz'in elinde şimdi kaç } \\
\text { balon vardır? } \\
\text { Sembolik modeli: } 3+2=\text { ? }\end{array}$ & $\begin{array}{l}\text { Deniz'in elinde } 3 \text { balon } \\
\text { vard. Berke de Deniz'e } \\
\text { birkaç balon verdi. } \\
\text { Deniz'in elinde şimdi } \\
\text { toplam } 5 \text { balon olduğuna } \\
\text { göre Berke Deniz'e kaç } \\
\text { balon vermiştir? } \\
\text { Sembolik modeli: } 3+?=5\end{array}$ & $\begin{array}{l}\text { Deniz'in elinde birkaç balon } \\
\text { vardi. Berke de Deniz'e iki } \\
\text { balon verdi. Deniz'in elinde } \\
\text { şimdi toplam } 5 \text { balon } \\
\text { olduğuna göre Deniz'in } \\
\text { elinde başlangıçta kaç balon } \\
\text { vardı? } \\
\text { Sembolik modeli: ?+2=5 }\end{array}$ \\
\hline $\begin{array}{l}\text { Ada'nın elinde } 5 \text { bebek vardı. } \\
3 \text { tanesini Nazlı'ya verdi. } \\
\text { Ada'nın elinde kaç bebek } \\
\text { kaldı? } \\
\text { Sembolik modeli: } 5-3=\text { ? }\end{array}$ & $\begin{array}{l}\text { Ada'nın elinde } 5 \text { bebek } \\
\text { vardı. Birkaç tanesini } \\
\text { Nazlı'ya verdi. Ada'nın } \\
\text { elinde şimdi } 2 \text { bebek } \\
\text { kaldı. Ada Nazlı'ya kaç } \\
\text { bebek vermiştir? } \\
\text { Sembolik modeli: } 5-?=2\end{array}$ & 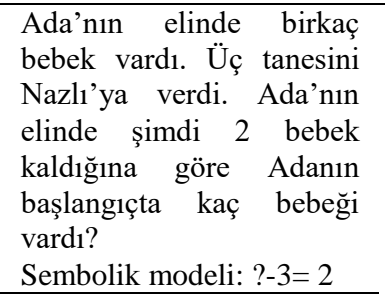 \\
\hline
\end{tabular}


Tablo 1 (devam)

\begin{tabular}{|c|c|c|}
\hline \multicolumn{3}{|c|}{ Parça-Parça-Bütün } \\
\hline Bütün bilinmeyenli & Parça bilinmeyenli & \\
\hline $\begin{array}{l}\text { Ege'nin } 3 \text { tane naneli } 2 \text { tane } \\
\text { meyveli sakızı vardı. Ege'nin } \\
\text { toplam kaç sakızı vardır? } \\
\text { Sembolik modeli: } 3+2=\text { ? }\end{array}$ & $\begin{array}{l}\text { Ege'nin } 3 \text { tane naneli } \\
\text { birkaç tanesi meyveli olan } \\
\text { toplam 5 sakız vard1. } \\
\text { Ege'nin meyveli kaç } \\
\text { sakızı vardır? } \\
\text { Sembolik modeli: } 3+?=5\end{array}$ & \\
\hline \multicolumn{3}{|c|}{ Karşılaștırma } \\
\hline Fark bilinmeyenli & Büyük bilinmeyenli & Küçük bilinmeyenli \\
\hline $\begin{array}{l}\text { Aslı'nın } 6 \text { çikolatası vardır, } \\
\text { Duru'nun ise } 4 \text { çikolatası } \\
\text { vardır. Aslı'nın Duru'dan kaç } \\
\text { tane fazla çikolatası vardır? } \\
\text { Sembolik modeli: } 6-4=?\end{array}$ & $\begin{array}{l}\text { Aslı'nın Durudan } 2 \text { tane } \\
\text { fazla çikolatas1 vardır. } \\
\text { Duru'nun } 4 \text { çikolatas1 } \\
\text { olduğuna göre Aslı'nın } \\
\text { kaç tane çikolatası vardır? } \\
\text { Sembolik modeli: } 4+2=\text { ? }\end{array}$ & $\begin{array}{l}\text { Aslı'nın Duru'dan } 2 \text { tane az } \\
\text { çikolatası vardır. Aslı'nın } 4 \\
\text { çikolatası olduğuna göre } \\
\text { Duru'nun kaç tane } \\
\text { çikolatası vardır? } \\
\text { Sembolik modeli: } 4-2=?\end{array}$ \\
\hline
\end{tabular}

Toplama ve çıkarma işlemlerine ilişkin sözel problem türleri, bu 11 alt kategoriye göre incelendiğinde;

Birleştirme türü problemlerde, başlangıç bilinmeyenli (initial unknown), değişim bilinmeyenli (change unknown) ve sonuç bilinmeyenli (result unknown) olmak üzere üç tür yer almaktadır. Başlangıç bilinmeyenli problem türünde problemin başlangıç miktarı verilmemiştir. Değişim bilinmeyenli problem türünde ortadaki veri verilmemiş ve ortadaki miktar istenmektedir. Sonuç bilinmeyenli problem türünde ise sonuç miktarı istenmektedir.

Ayırma türü problemlerde, birleştirme modeli gibi başlangıç bilinmeyenli, değişim bilinmeyenli ve sonuç bilinmeyenli olmak üzere üç bilinmeyen türünden oluşmaktadır. Başlangıç bilinmeyenli problem türünde başlangıç miktarı verilmemiştir ve başlangıç miktarı istenilmektedir. Değişim bilinmeyenli problem türünde ortadaki değişken verilmemiş ve ortadaki değişkenin bulunması istenilmektedir. Sonuç bilinmeyenli problem türünde, sonuç verilmemiş ve sonucun bulunması istenilmektedir. Ayırma modeli problem türlerinde parçadan ayrılma yani çıkarma söz konusudur. Ayırma problemlerinde farkına varılması gereken şey, başlangıç miktarı bütünün en büyük miktarı olmalıdır. Oysa birleştirme problemlerinde sonuç miktarı bütünün miktarıdır.

Parça-Parça-Bütün türü problemlerde, bütün bilinmeyenli (whole unknown) ve parça bilinmeyenli (part unknown) olarak iki problem türü yer almaktadır. Bütün bilinmeyenli problemlerde, bütünün parçaları verilmekte ve bütünü sorulmaktadır. Parça bilinmeyenlide ise bütün verilmekte ve parçası sorulmaktadır. Diğer problem modellerinde üç bilinmeyen türünde problemler varken parça-parça-bütün problemlerinde iki bilinmeyen türü vardır. 
Karşılaştırma türü problemlerde, iki özelliğin karşılaştırması istenir. Üçüncü miktar sunulmaz. Ama aslında üçüncü miktar iki miktar arasındaki farktır. Karşılaştırma problemlerinde fark bilinmeyen (difference unknown), büyük bilinmeyen (larger unknown) ve küçük sayı bilinmeyen (smaller unknown) olmak üzere üç tür söz konusudur. Fark bilinmeyenli problem türünde, verilenler arasındaki fark bilinmemektedir. Büyük bilinmeyenli problem türünde aradaki fark bilinir ancak büyük bilinmeyenin bulunması istenir. Küçük bilinmeyenli problem türünde ise aradaki fark verilir ve küçük bilinmeyenin bulunması istenir.

Toplama ve çıkarma işlemlerine ilişkin sözel problem türlerine ilişkin yapılan bazı çalışmalar incelendiğinde; hem yukarıda söz edilen türlerin ders ve etkinlik kitaplarında çok sınırlı düzeyde yer verildiğini (Desli ve Loukidou, 2014; Olkun ve Toluk, 2002; Parmjit, 2006; Parmjit ve Teoh, 2010; Sarıbaş ve Aktaş-Arnas, 2017; Tarım, 2017) hem de öğretmenlerin bu problem türlerini çocuklara yeterince sunmadığını (Nunes ve Bryant, çev. 2008; Sarıbaş ve Aktaş-Arnas, 2016, 2017; Sperry-Smith, 2001) göstermektedir. Dolayısıyla çocuklar toplama ve çıkarma işlemlerine ilişkin sınırlı çeşitlilikte sözel problem türleri ile karşılaşmaktadırlar.

$\mathrm{Bu}$ anlamda, çocukların yaşamları boyunca matematiği anlama, keşfetme ve kullanma yolculuğunda öğretmenlerin önemli bir rolü olduğu bir gerçektir. Umay (2003) da çocukların matematiğe ilişkin olumlu duygular oluşturmaları için okul öncesi dönemde öğretmen rolünün önemini vurgulamış ve öğretmenlerin matematiksel kavramları ve bu kavramları nasıl öğreteceğini iyi bilmesi gerektiğini belirtmiştir.

\section{Öğretmenin Rolü}

Çocukların toplama ve çıkarma işlemlerine ilişkin sözel problem kurabilme beceri ve yeterliklerine sahip olmasında en önemli etkenlerden biri öğretmenler ve dolayısıyla geleceğin öğretmenleri olan öğretmen adaylarıdır. Öğretmenlerin ve öğretmen adaylarının, sözel problem kurma konusunda gerekli bilgi ve becerilere sahip olması ve farklı problem türlerine ilişkin farkındalıkların yüksek olması bu becerileri sınıf ortamına aktarması açısından önemlidir. Farkındalık düzeyi yüksek öğretmenler, çocuklara tekdüze sözel problem kurma çalışmaları yaptırmak yerine sözel problem türlerinin birçoğuna yer vererek onların üst bilişsel becerilerinin gelişmesine ve problem çözme süreçlerini kullanmasına katkı sağlayacaktır. Öğretmenlerin matematiği etkili bir şekilde öğretme becerisi ve matematiksel bilgisinin öğrenci başarısı üzerinde önemli etkisinin olduğunu belirten çalışmalar bulunmaktadır (Hill, Rowan ve Ball, 2005; Swars, Hart, Smith, Smith ve Tolar, 2007; Thompson, 1984). Örneğin, Hill ve diğ. (2005) yaptıkları çalışmada, öğretmenin sahip olduğu matematik bilgisinin, çocukların matematik başarıları üzerinde etkili olduğu sonucuna ulaşmıştır. Bu bulgu ile aynı zamanda öğretmenlerin matematik bilgisi ile çocukların matematik başarılarını geliştirilebileceği belirlenmiştir. Sonuç olarak öğretmenlerin, çocukların matematiksel bilgi ve becerilerini etkilemeleri ve geliştirmelerinin yanı sıra çocuklara sundukları ögretimsel uygulamalar ile çocukların matematiği anlama ve anlamlandırmalarında önemli bir rolü vardır. 
$\mathrm{Bu}$ bağlamda çocukların matematiksel bilgi ve beceriler konusunda yetkin olabilmeleri için öncelikle öğretmenlerin ve dolayısıyla öğretmen adaylarının matematiksel bilgi, beceri ve farkındalıklarının yeterli düzeyde olması gerekmektedir. Çünkü öğretmen, bir değişimin, bir yeniliğgin gerektirdiği bilgi ve becerilere sahip olursa, çocukların gelişmesini sağlayabilir. Bu nedenle, öncelikle eğitim öğretimin önemli öğelerinden biri olan öğretmenlerin söz konusu alanda yeterliğinin sağlanması gereklidir. Gelecek kuşakları yetiştirecek olan öğretmen ve öğretmen adaylarının farkındalık, beceri ve yeterliklerini ortaya çıkarmayı hedefleyen çalışmalar, daha nitelikli bir öğretmen yetiştirme programının hazırlanması açısından önemlidir.

Çocukların toplama ve çıkarma işlemlerine ilişkin sözel problem türlerini kurma ve çözme becerilerinde başarılı olabilmeleri için bu sözel problem türlerini deneyimlemeleri önemlidir. Öğretmenler tarafından sınıf içi uygulamalarda bu problem türlerinin hepsine öğrencilerin bu alandaki becerilerini geliştirecek seviyede yer verilmesi gereklidir (Nunes ve Bryant, çev. 2008; Peterson, Fennema ve Carpenter, 1989; Sperry-Smith, 2001; Van De Walle ve diğ., 2016). Ancak yapılan çalışmalar okul öncesi öğretmenlerinin çocuklara sözel problem türlerini yeterince sunmadığını göstermektedir (Nunes ve Bryant, çev. 2008; Sarıbaş ve Aktaş-Arnas, 2017; Sperry-Smith, 2001). Öğretmenlerin çocuklara sundukları sözel problem türlerinin çoğunlukla sonuç bilinmeyenli problemler olduğu görülmektedir (Carpenter, Fennema, Peterson, Chiang ve Leaf, 1989; Nunes ve Bryant, çev. 2008).

Türkiye'de toplama ve çıkarma işlemlerine ilişkin sözel problem kurma ve çözme becerilerine yönelik çalışmaların çoğunlukla matematik öğretmeni, sınıf öğretmeni veya ilkokul ve ortaokul öğrencileri üzerine yoğunlaştığı görülmektedir (Işık ve Kar, 2011; İnel, Evrekli ve Türkmen, 2011; Kayan ve Çakıroğlu, 2008; Korkmaz ve Gür, 2016; Serin, 2010; Tertemiz ve Sulak, 2013; Ulu, 2008). Okul öncesi öğretmenleri ve öğretmen adayları üzerine yapılan çalışmalar ise oldukça sınırlıdır. Yapılan bu çalışmalarda da öğretmenlerin çocuklar için seçtikleri sözel problem türleri üzerine yoğunlaşılmıştır. Bulgular okul öncesi öğretmenlerinin toplama ve çıkarma işlemleri içeren farklı sözel problem türlerini öğrencilerine yeterince sunmadıklarını göstermektedir (Sarıbaş ve Aktaş-Arnas, 2016, 2017).

$\mathrm{Bu}$ araştırmada okul öncesi öğretmenlerinin ve öğretmen adaylarının sözel problem kurma becerilerinin daha önce incelenmemiş olmasından dolayı okul öncesi öğretmenleri ve öğretmen adayları ile yürütülmüştür. Bu araştırmanın sonunda hem öğretmenler için hem de okul öncesi dönemi çocuklar için eğitim materyalleri hazırlayan uzmanlar için de bir farkındalık oluşturulması hedeflenmiştir. Ayrıca yükseköğretim kurumu öğretmenlik programlarından okul öncesi eğitim programında bir ders olarak okutulan okul öncesinde matematik eğitimi dersinin içerik planlamasına da önemli katkılar sunacaktır.

Yukarıda belirtilen nedenlerden dolayı araştırmanın amacı, okul öncesi öğretmenlerinin ve öğretmen adaylarının toplama ve çıkarmaya ilişkin sözel problem kurma becerilerini incelemek olarak belirlenmiştir. Bu amaçla aşağıdaki sorulara yanıt aranmıştır: 
1. Okul öncesi öğretmen ve öğretmen adaylarının,

a. Toplama ve çıkarmaya ilişkin kurdukları sözel problem türleri nelerdir?

b. Oluşturulan problemler okul öncesi çocukların gelişimine uygun mudur?

\section{Yöntem}

$\mathrm{Bu}$ başlık altında araştırma modeli, çalışma grubu, veri toplama araçları, verilerin toplanma süreci ve veri analizinde yapılan işlemler hakkında bilgiler verilmiştir.

\section{Araştırma Modeli}

$\mathrm{Bu}$ çalışmada, nicel araştırma yöntemlerinden tarama modeli kullanılmıştır. Tarama modeli bir topluluğun bir konuyla ilgili görüşlerinin ya da özelliklerinin betimlenmesi amacıyla yapılan araştırmalarda kullanılır (Büyüköztürk, Çakmak, Akgün, Karadeniz ve Demirel, 2010). Araştırmanın verileri Sözel Problem Kurma Formu kullanılarak toplanmıştır.

\section{Calıșma Grubu}

$\mathrm{Bu}$ araştırma, iki farklı çalışma grubundan oluşturulmuştur. Bunlardan biri okul öncesi öğretmenleri, diğeri ise okul öncesi öğretmen adaylarıdır. Araştırmanın birinci çalışma grubunu Adana ili merkez ilçelerinde bulunan İl Milli Eğitim Müdürlüğüne bağlı 41 bağımsız anaokulunda görev yapan ve araştırmaya katılmaya istekli olan 93 okul öncesi öğretmeni oluşturmuştur. Araştırmaya dahil olan öğretmenlerin 88'i kadın, 3'ü erkek öğretmenlerden oluşurken 2 öğretmen cinsiyet belirtmemiştir. Öğretmenlerin \%2.2'si lise, \% 90.3'ü lisans, \%4.3'ü önlisans ve \%3.2'si yüksek lisans mezunu olup \% 17.2'si 0-5 yıl, \% 45.2'si 6-10 yıl, \% 26.9'u 11-15 y1l, \% 9.7'si ise 16 ve üzeri yıl mesleki deneyime sahiptir.

Araştırmanın ikinci çalışma grubunu ise Adana'da bulunan bir devlet üniversitesinde, 2016-2017 öğretim yılında Okul Öncesi Öğretmenliği Anabilim Dalında öğrenim görmekte olan 164'ü kadın ve 15'i erkek öğretmen adayından oluşan 179 üçüncü ve dördüncü sınıf öğrencisi oluşturmaktadır. Üç ve dördüncü sınıfa giden öğretmen adaylarının seçilme nedeni, okul öncesinde matematik eğitimi dersini almış olmaları ve öğretmenlik uygulamalarına gidiyor olmalarıdır. Öğretmen adaylarının seçimi kolay ulaşılabilir durum örneklemesi yöntemi ile yapılmıştır.

\section{Veri Toplama Araçları}

Çalışmada veri toplama aracı olarak öğretmenlerin ve öğretmen adaylarının sözel problem kurma becerilerini belirlemek için araştırmacılar tarafindan Sözel Problem Kurma Formu oluşturulmuştur. Oluşturulan formda yer alan sembolik matematiksel ifadelerin okul öncesi dönemdeki çocukların gelişim düzeyine uygun olup olmadığı alanda çalışan iki okul öncesi öğretmeni ile toplama ve çıkarmaya ilişkin sözel problemler konusunda çalışmaları olan iki öğretim elemanına sunulmuştur. Onlardan gelen dönütler doğrultusunda forma son şekli verilmiştir. 
Formda katılımcılara, toplamaya ilişkin üç ve çıkarmaya ilişkin üç olmak üzere toplam altı sayısal sembollerden oluşan işlem sorusu sorulmuştur. Öğretmen ve öğretmen adaylarından bu sembolik işlem sorularını, toplama ve çıkarmaya ilişkin sözel problemlere dönüştürmeleri istenmiştir. Öğretmen ve öğretmen adaylarından birleştirme, ayırma, parça-bütün ve karşılaştırma işlem türlerinde 11 alt kategoride sözel problem kurmaları beklenmiştir.

\section{Verilerin Toplanması}

Verilerin toplanması sırasında Adana il Milli Eğitim Müdürlüğü'ne bağlı bağımsız anaokullarına gidilerek okul yöneticileriyle ve öğretmenler ile görüşülmüştür. $\mathrm{Bu}$ görüşmelerde araştırmanın içeriği anlatılmıştır. Araştırmaya katılma konusunda gönüllü olan öğretmenlere Sözel Problem Kurma Formu verilmiştir. Öğretmenlerden bu formda yer alan işlemlere yönelik bireysel olarak problemler kurmaları istenmiştir.

Benzer işlem öğretmen adaylarının öğrenim görmekte oldukları anabilim dalında bir ders saatinde toplu bir şekilde gerçekleştirilmiştir. Öğretmen adaylarına Sözel Problem Kurma Formu dağııılmış ve gerekli açıklamalar yapıldıktan sonra bireysel olarak problemler kurmaları istenmiş̧ir. Veri toplama işlemi her iki grupta da ortalama 40 dakika sürmüştür.

\section{Verilerin Analizi}

Sözel Problem Kurma Formunda yer alan toplama ve çıkarma işlemine ilişkin sembolik işlemler, öğretmenler ve öğretmen adayları tarafından sözel problemlere dönüştürülmüştür. Daha sonra kurulan sözel problemler, toplamaya ilişkin dört sözel problem türü ve 11 alt kategori temel alınarak araştırmacılar tarafından tek tek incelenmiştir.

Verilerin analizi sürecinde her iki araştırmacı birlikte çalışmışlar ve problem türlerini birlikte tartışarak değerlendirmişlerdir. Öğretmenlerin ve öğretmen adaylarının kurduğu her sözel problem türü doğru ise başarllı ve 1 puan olarak puanlanmış, yanlış ise başarısız ve 0 puan olarak değerlendirilmiş̧ir. Değerlendirmeden sonra elde edilen puanlardan frekans ve yüzde değerler hesaplanmıştır.

Daha sonra öğretmenler ve öğretmen adayları tarafindan kurulan sözel problemlerin okul öncesi çocukların gelişim düzeyine uygun olup olmaması, problemde kullanılan dil bilgisi yapısı (kişi zamirleri), problemde sözü edilen kavramların ve sözcüklerin somut ve soyut olmasına göre de tek tek analiz edilmiştir. $\mathrm{Bu}$ analizlerde izlenilen yol aşağıda açıklanmıştır.

Öğretmenlerin ve öğretmen adaylarının kurdukları sözel problemlerde problemlerin çocukların gelişim düzeyine uygun olup olmadığı incelenirken

- seçilen sözcüklerin soyut (beş lira, görev vb.), somut (kalem, lego, elma) sözcükleri ve durumları içerip içermediği, 
- $\quad$ problem içinde seçilen sözcüklerin çocuğun yaş düzeyine göre uygun olup olmaması (Örneğin, ruj),

- kurulan cümlelerin matematiksel mantıksal çıkarıma izin vermemesi (Örneğin, beş tane çiçeğimin kalması için vazodaki çiceklerden dört tanesi kurusun.),

- $\quad$ problemin sayı sembolü ile kurulması (Örneğin, "4 ile hangi sayıyı toplarsan 9 olur?” gibi),

- $\quad$ problemin çok uzun olması (Örneğin, arkadaşlarının yanına parka geldiğinde misketlerini sayan Ali, 9 misketi olduğunu gördü. Evden parka ilk geldiğinde 4 misketi vardı. Su içmeye gittiğinde biraz daha misket almıştı ve misketleri 9 tane olmuştu. Ali su içmeye gittiğinde evden kaç misket almıştır?) gibi durumlar temel alınmıştır.

Doğru kullanımlar uygun ve 1 puan olarak puanlanmış, yanlış ve hatalı kullanımlar ise uygun değil ve 0 puan olarak değerlendirilmiştir.

Öğretmenlerin ve öğretmen adaylarının kurdukları sözel problemlerde ismin yerini tutan sözcük (kişi zamiri) seçimleri de incelenmiştir. Problemdeki kişi zamiri çocuğun kendisini belirterek kurulmuş ve sen / senin gibi sözcükler kullanılmış ise 1 puan, ben / benim veya $o$ / onun gibi sözcükler kullanılmış ise 0 puan verilmiştir. Örneğin, "Çantamdaki elmalardan beş tanesini arkadaşıma verince çantamda dört elma kaldı. En başta çantamda kaç tane elma vardı?” (ben kişi zamirini kullanması) veya "Evinizde beş karpuz var. Babanız üç tane daha aldı. Kaç karpuzunuz oldu?" (sen kişi zamirini kullanması). Daha sonra elde edilen puanlar üzerinden frekans ve yüzde değerleri elde edilmiştir.

\section{Bulgular}

Bu başlık altında okul öncesi öğretmenlerinin ve öğretmen adaylarının, toplama ve çıkarma işlemine ilişkin kurdukları sözel problem türlerine ve bu problemlerin okul öncesi çocuklara uygun olup olmamasına ilişkin analiz sonuçları aşağıda sunulmuştur. Öğretmenlerin ve öğretmen adaylarının toplama ve çıkarmaya ilişkin kurdukları sözel problem türleri Tablo 2'de sunulmuştur.

Tablo 2

Öğretmenlerin ve Öğretmen Adaylarının Kurdukları Toplama ve Çıkarma Işslemlerine Illişkin Sözel Problem Türlerinin Dă̆llımı

\begin{tabular}{llccccc}
\hline $\begin{array}{l}\text { Sözel Problem } \\
\text { Türleri }\end{array}$ & \multirow{2}{*}{ Kategoriler } & Örnek & \multicolumn{2}{c}{ Öğretmen } & \multicolumn{2}{c}{ Ögrretmen Adayı } \\
& & Problemler & f & \% & f & \% \\
\hline \multirow{3}{*}{ Birleştirme } & Sonuç bilinmeyenli & $5+3=?$ & 88 & 94.6 & 149 & 83.2 \\
\cline { 2 - 8 } & Başlangıç bilinmeyenli & $?+3=7$ & 46 & 49.5 & 68 & 38.0 \\
\cline { 2 - 8 } & Değişim bilinmeyenli & $4+?=9$ & 79 & 84.9 & 142 & 79.3 \\
\hline & & & & & \multicolumn{2}{c}{ (devam ediyor) }
\end{tabular}


Tablo 2 (devam)

\begin{tabular}{llccccc}
\hline $\begin{array}{l}\text { Sözel Problem } \\
\text { Türleri }\end{array}$ & \multirow{2}{*}{ Kategoriler } & Örnek & \multicolumn{2}{c}{ Öğretmen } & \multicolumn{2}{c}{ Öğretmen Adayı } \\
& Problemler & f & \% & f & \% \\
\hline \multirow{3}{*}{ Ayırma } & Sonuç bilinmeyenli & $6-2=?$ & 90 & 96.8 & 165 & 92.2 \\
\cline { 2 - 7 } & Başlangıç bilinmeyenli & $?-4=5$ & 74 & 79.6 & 142 & 79.3 \\
\cline { 2 - 7 } & Değişim bilinmeyenli & $8-?=3$ & 81 & 87.1 & 153 & 85.5 \\
\hline Parça-Parça- & Bütün bilinmeyenli & $3+5=?$ & 6 & 6.5 & 22 & 12.3 \\
\cline { 2 - 7 } Bütün & Parça bilinmeyenli & $3+?=8$ & 10 & 10.7 & 11 & 6.1 \\
\hline \multirow{3}{*}{ Karşılaştırma } & Fark bilinmeyenli & $6-2=?$ & - & - & 1 & 0.6 \\
\cline { 2 - 7 } & Büyük bilinmeyenli & $5+3=?$ & - & - & - & - \\
\cline { 2 - 7 } & Küçük bilinmeyenli & $4+?=9$ & 1 & 1.1 & - & - \\
\hline
\end{tabular}

Tablo 2'ye göre öğretmenlerin birleştirme türü sözel problemlerden Sonuç bilinmeyenli (\% 94.6) ve Değişim bilinmeyenli (\% 84.9) problem tiplerini kurmada daha başarılı olurken Başlangıç bilinmeyenli (\% 49.5) problem tipinde daha az başarılı oldukları bulunmuştur. Ayrıca öğretmenlerin çoğunluğunun ayırma türü sözel problemlerden Sonuç bilinmeyenli (\% 96.8), Değişim bilinmeyenli (\% 87.1) ve Başlangıç bilinmeyenli (\% 79.6) problem türlerini kurmada oldukça başarılı oldukları saptanmıştır. Bununla birlikte parça-parça-bütün türü sözel problemler kurmada ise öğretmenlerin çok az bir kısmının [Bütün bilinmeyenli (\% 6.5), Parçası bilinmeyenli (\%10.7)] başarılı oldukları belirlenmiş̧tir. Karşılaştırma türü sözel problemleri kurmada ise ne yazık ki öğretmenlerin tamamı, başarılı olamamıştır. Sadece bir öğretmen Küçük bilinmeyenli problem tipini kurmada başarılı olmuştur.

Öğretmen adaylarının toplama ve çıkarma işlemlerine ilişkin kurdukları sözel problem türleri incelendiğinde ise, öğretmen adaylarının çoğunluğunun da birleştirme türü sözel problemlerden Sonuç bilinmeyenli (\% 83.2), Değişim bilinmeyenli (\% 79.3) problem tiplerini kurmada daha başarılı olurken Başlangıç bilinmeyenli (\% 38) problem tipinde daha az başarılı oldukları belirlenmiştir. Öğretmen adaylarının çoğunluğunun ayırma türü sözel problemlerden Sonuç bilinmeyenli (\% 92.2), Değişim bilinmeyenli (\% 85.5) ve Başlangıç bilinmeyenli (\% 79.3) problem türlerini kurmada ise daha başarılı oldukları saptanmıştır. Bununla birlikte öğretmen adaylarının parça-parça-bütün türü sözel problemleri kurmada [Bütün bilinmeyenli (\% 12.3), Parça-parça-bütün / Parçası bilinmeyenli (\% 6.1)] çok küçük bir bölümünün başarı gösterdikleri bulunmuştur. Çalışmada öğretmen adaylarının Karşılaştırma türü sözel problemleri kurmada ise ne yazık ki tamamın başarısız olduğu, sadece bir öğretmen adayının Fark bilinmeyenli (\% 0.6) problem tipini kurmada başarılı olduğu saptanmıştır.

Genel olarak değerlendirildiğginde, öğretmenlerin ve öğretmen adaylarının çıkarma işlemine ilişkin (ayırma problemlerinden) sonuç, değişim ve başlangıç bilinmeyenli problem tiplerini kurmada daha başarılı oldukları belirlenirken toplama işlemine ilişkin (birleştirme problemlerinden) sonuç ve değişim bilinmeyenli problem tiplerini kurmada daha başarılı oldukları belirlenmiștir. Öğretmen ve öğretmen adayının çok azının parça-parça-bütün problemlerini kurmada başarı gösterdikleri, 
karşılaştırma problem türlerini kurmada ise hemen hemen hiç birinin başarılı olamadıkları bulunmuştur.

Öğretmenlerin ve öğretmen adaylarının toplama ve çıkarmaya ilişkin kurdukları sözel problem türlerinin okul öncesi çocukların gelişim düzeyine uygun olup olmaması, problemin içinde geçen kavram ve sözcüklerin somut / soyut olması, seçilen sözcüklerin çocuğun yaş düzeyine uygun olup olmaması, kurulan cümlelerin matematiksel mantıksal çıkarıma izin vermemesi, problemin sayı sembolü ile kurulması ve problemin çok uzun olması temel alınarak değerlendirilmiştir. Ayrıca öğretmen ve öğretmen adaylarının sözel problemleri kurarken problemde ismin yerini tutan sözcük seçimleri de analiz edilmiş ve sonuçları Tablo 3'te sunulmuştur.

Tablo 3

Kurulan Sözel Problem Türlerinin Okul Öncesi Çocuklara Uygunluğu

\begin{tabular}{lcc}
\hline Kriterler & Öğretmenler (\%) & Öğretmen Adayları(\%) \\
\hline Geliş̧im Düzeyine Uygunluk & 89.2 & 85.5 \\
Somut Kavram ve Sözcükler Kullanma & 96.2 & 91.5 \\
Tercih Edilen Şahıs Zamiri & 34.7 & 28.4 \\
\hline
\end{tabular}

Yapılan analizlere göre öğretmenlerin toplama ve çıkarma işlemlerine ilişkin kurdukları sözel problemlerin büyük çoğunluğunun okul öncesi çocukların gelişim düzeylerine uygun (\% 89.2) olduğu belirlenmiştir. Ayrıca öğretmenlerin kurdukları sözel problemlerin içinde geçen kavram ve sözcüklerin büyük çoğunluğunun da çocukların gelişim düzeyleri dikkate alınarak somut kavram ve sözüklerden (\% 96.2) oluştuğu saptanmıştır. Öğretmenlerin yaklaşık üçte birinin (\% 34.7) kurdukları sözel problemlerde isim yerini tutan sözcük olarak sen kişi zamirini tercih ettikleri bulunmuştur.

Öğretmen adaylarının toplama ve çıkarma işlemlerine ilişkin kurdukları sözel problemlerin büyük çoğunluğunun da okul öncesi çocukların gelişim düzeylerine uygun problemler olduğu (\% 85.5) ve problemin içinde geçen kavram ve sözcüklerin büyük çoğunluğunun (\% 91.5) somut kavram ve sözüklerden oluştuğu bulunmuştur. Öğretmen adaylarının üçte birinden (\% 28.4) daha azının kurdukları sözel problemlerde isim yerini tutan sözcük olarak sen kişi zamirini tercih ettikleri bulunmuştur.

\section{Tartışma, Sonuç ve Öneriler}

Okul öncesi öğretmenlerinin ve öğretmen adaylarının toplama ve çıkarma işlemlerine ilişkin sözel problem kurma becerilerini incelemek amacıyla planlanan bu araştırmanın sonuçları alanyazına önemli katkılar sunmaktadır.

Okul öncesi öğretmenlerinin ve öğretmen adaylarının toplama ve çıkarmaya ilişkin kurdukları sözel problem türleri incelendiğinde, öğretmenlerin ve öğretmen adaylarının ayırma türü sözel problemlerden sonuç, değişim ve başlangıç bilinmeyenli 
problem türlerini kurmada diğerlerine nazaran başarılı olurken birleştirme türü sözel problemlerden sonuç ve değişim bilinmeyenli problem türlerini kurmada daha başarılı oldukları belirlenmiştir. Ancak ne yazık ki öğretmenlerin ve öğretmen adaylarının çok azı parça-parça-bütün problemlerini kurmada başarı gösterebilmişlerdir. Karşılaştırma türü problemleri kurmada ise öğretmenler ve öğretmen adayları hiçbir başarı gösterememişlerdir. Belirlenen sonuçlar öğretmenlerin ve öğretmen adaylarının çoğunlukla aynı tür ve aynı kurguda sözel problemler kurabildiklerini göstermektedir.

Türkiye'de ve yurtdışındaki ilgili alanyazın incelendiğinde de benzer bulgulara ulaşılmıştır. Örneğin, Türkiye'de Sarıbaş ve Aktaş-Arnas (2017) tarafından 325 okul öncesi öğretmeni ile yapılan bir çalışmada, okul öncesi öğretmenlerinin çocuklara en çok sonuç bilinmeyenli ve parça bilinmeyenli sözel problem türlerini sundukları belirlenmiştir. Ancak bu çalışmada öğretmenlerin ve öğretmen adaylarının ayırma türü sözel problemlerden her üç (sonuç, değişim ve başlangıç bilinmeyenli) problem türünü kurmada ve sözel problemlerden sonuç ve değişim bilinmeyenli problem türlerini kurmada oldukça başarılı oldukları belirlenmiştir. Bu sonuç öğretmenlerin bu sözel problem türlerine ilişkin bilgilerinin ve farkındalıklarının olduğunu ancak çocuklara sunarken bu problem türlerini tercih etmediklerini göstermektedir. $\mathrm{Bu}$ çalışmada öğretmenler ve öğretmen adaylarının diğer sözel problem türleri olan parça-parça bütün ve karşılaştırma problem türlerini kurmada başarılı olamadıkları belirlenmiştir. Sarıbaş ve Aktaş-Arnas'ın (2017) çalışmasında da bu iki sözel problem türünün (parçası bilinmeyen hariç) öğretmenler tarafından çocuklara çok az sunulduğu saptanmıştır.

Sarıbaş ve Aktaş-Arnas (2016) tarafından öğretmenlerle birebir görüşmeler yoluyla yapılan bir başka çalışmada da öğretmenlerin, çocuklara toplama ve çıkarmayla ilgili problemler sunarken çoğunlukla sonuç bilinmeyenli sözel problemler tercih ettiklerini belirtmişlerdir. Öğretmenler, okul öncesi eğitimde kullanılan kaynak kitaplarda bazı sözel problem türlerine yer verilmediğini bu nedenle de bu sözel problem türlerini çocuklara sunmadıklarını belirtmişlerdir. Sarıbaş ve Aktaş-Arnas'ın (2016) yaptığ ç̧alışma da öğretmenlerin çocuklara çoğunlukla sonuç bilinmeyenli problem türlerini sunduklarını göstermektedir. İlgili çalışmada öğretmenlerin sözel problem türleri ile ilgili yeterince bilgi sahibi olmadıkları saptanmıştır. Aynı zamanda elde edilen bu sonuçlar uluslararası alanyazında yer alan çalışmalarla da benzer sonuçlar göstermektedir (Carpenter ve diğ., 1989; Nunes ve Bryant, çev. 2008).

Çalışmadan elde edilen bir diğer sonuç ise öğretmen ve öğretmen adaylarının toplama ve çıkarma ile ilgili sözel problem türlerine ilişkin yeterli bilgiye sahip olmadıklarını ve farkındalıklarının düşük olduğunu göstermektedir. Bunun en temel nedenlerinden birisi öğretmen ve öğretmen adaylarının kendi öğrenim yaşamlarında genellikle çözümü tek aşamalı olan sözel problem türleri ile karşılaşmış olmalarıdır. Bir diğer nedeni ise matematik etkinlik kitaplarında genellikle sonuç bilinmeyenli problemlere daha fazla yer veriliyor olması ve diğer problem türlerinin göz ard1 edilmesidir (Desli ve Loukidou, 2014; Sarıbaş ve Aktaş-Arnas, 2017; Parmjit, 2006; 
Parmjit ve Teoh, 2010). Bunun bir sonucu olarak da öğretmen ve öğretmen adayları çocuklar için kullandıkları yazılı materyallerde hep aynı tür problemler ile karşılaşmaktadırlar. Sarıbaş ve Aktaş-Arnas (2017) içinde toplama ve çıkarmaya ilişkin sözel problemlere yer veren 57 matematik etkinlik kitabını incelendikleri çalışmada, etkinlik kitaplarının büyük çoğunluğunun sadece sonuç bilinmeyenli problem örneklerine (birleştirme-sonuç bilinmeyenli \% 84.2 ve ayırma-sonuç bilinmeyenli \% 78.9) yer verirken diğer problem türlerine hiç yer vermediklerini saptamıştır.

$\mathrm{Bu}$ araştırmada öğretmenlerin ve öğretmen adaylarının toplama ve çıkarmaya ilişkin sözel problemler kurarken dikkat ettikleri ölçütler incelenmiş ve büyük çoğunluğunun okul öncesi çocukların gelişim düzeyine uygun problemler kurdukları belirlenmiştir. Araştırmada öğretmenlerinin ve öğretmen adaylarının büyük çoğunluğunun okul öncesi çocukların gelişim düzeyine uygun sözel problemler kurmaları onların eğitim süreçleri boyunca aldıkları eğitimle yakından ilgilidir. Öğretmen adayları eğitim süreçlerinde hem çocuk gelişimi hem de öğretim bilgisi ile ilgili pek çok ders almakta ve uygulamalar yapmaktadır. Bu sürecin onların bu konudaki bilgi ve becerilerini artırdığı söylenebilir. Elde edilen sonuçları, Sarıbaş ve Aktaş-Arnas (2017) tarafından okul öncesi öğretmenlerin çocuklara sundukları sözel problemler ile ilgili yapılan çalışmanın bulguları ile de benzerlik göstermektedir. İlgili çalışmada öğretmenler çoğunlukla sözel problemlerin çocukların gelişim düzeyine uygun olarak seçilmesi gerektiğini vurgulamışlardır.

$\mathrm{Bu}$ çalışmada öğretmenlerin ve öğretmen adaylarının büyük çoğunluğunun çocukların gelişim özelliklerinin yanı sıra kurdukları sözel problemlerde somut kavram ve sözcüklere de yer verdikleri saptanmıştır. Okul öncesi dönemi çocukların işlem öncesi dönemde olmaları ve soyut kavramları anlamamaları nedeniyle bu dönemde onlara sunulacak matematiksel bilgi ve kavramların da öncelikle somut materyaller, durumlar ile sunulması gerektiği ilgili alanyazında da belirtilmektedir (Akman, 2002; Aktaş-Arnas, 2012; Peterson ve Felton-Collins, 1986).

Ayrıca çalışmada öğretmenlerin ve öğretmen adaylarının üçte birinin kurdukları sözel problemlerde isim yerini tutan sözcük olarak sen kişi zamirini tercih ettikleri belirlenmiştir. Alanyazın incelendiğinde de çocuklara sunulan sözel problemlerde kullanılan dil bilgisi yapısının önemli olduğu ve problemlerde sen zamirinin kullanıldığı sözel problemlerde çocukların daha başarıları oldukları belirtilmiştir. Örneğin Dinç-Artut (2015), 5-6 yaş grubu çocuklarla yaptığı çalışmada, çocuklara önce sözel problemler orijinal şekli ile sunulmuş, başarısız olmaları durumunda problemler çocuğun kendisini ifade ederek sen kişi zamiri kullanılarak sunulmuştur. Araştırmada sen kişi zamiri kullanıldıktan sonra çocukların başarılarının \% 8 arttı̆ 1 saptanmıştır. d'Ailly, Simpson ve MacKinnon (1997) yaptıkları 3., 4. ve 5. sınıftaki çocuklarla yaptıkları bir çalışmada, sözel problemlerde, kişinin kendisini ifade eden kişi zamirleri kullandığında (yani sen kişi zamiri kullanıldığında) öğrencilerin performanslarının arttığı ve sen kişi zamiri kullanımının sözel problemleri çözmede kodlama işini kolaylaştırarak öğrencilerde çalışan belleğin (kısa süreli bellek) yükünü 
azalttığı belirlenmiştir. Bununla birlikte Stern (1993) yaptığı bir çalışmada, anasınıfı ve birinci sınıf öğrencileri ile yaptığı deneysel bir çalışmada, sözel problemlerde kişi zamirlerinin kullanılmasının çocukların sözel problemleri çözmedeki zorluklarını açıklayamadığııı belirtmiştir.

Okul öncesi öğretmenlerinin ve öğretmen adaylarının sözel problem kurma becerilerinin değerlendirildiği tarama modelindeki bu çalışmada, öğretmenlerin ve öğretmen adaylarının çoğunlukla birleştirme ve ayırma problemlerinden sonuç, değişim ve başlangıç bilinmeyenli problem türlerini kurma konusunda daha başarılı oldukları belirlenirken parça-parça-bütün problemlerinde ve karşılaştırma problem türlerini kurmada başarılı olamadıkları belirlenmiştir.

Okul öncesi öğretmenlerinin ve öğretmen adaylarının sözel problemleri kurarken dikkat ettikleri ölçütler incelenmiş ve öğretmen adaylarının büyük çoğunluğunun okul öncesi çocukların gelişim düzeyine uygun problemler kurdukları ve problemleri kurarken somut kavram ve sözcüklere yer verdikleri ile üçte birinin sözel problemleri kurarken sen kişi zamirini tercih ettikleri belirlenmiştir.

Elde edilen bu sonuçlar, öğretmenlerin ve öğretmen adaylarının sözel problem türlerine yönelik bilgi ve farkındalık düzeylerinin yetersiz olduğunu göstermektedir. Oysaki ilgili alanyazında da belirtildiği gibi, öğretmenlerin çocuklara sözel problemleri öğretebilmeleri ve onlara bu konuda gerekli becerileri kazandırmaları için öncelikle kendilerinin bu problemler ile ilgili bilgi sahibi olmaları gerekmektedir. Yani kendilerinin sözel problemleri anlamaları ve kurgulayabilmeleri önemli bir konudur. $\mathrm{Bu}$ anlamda öncelikle öğretmenlerin ve öğretmen adaylarının bu konudaki bilgilerini ve yeterliklerini artırmaları önerilebilir. Bu amaçla gerek öğretmenlere sunulan hizmet içi eğitim programlarında gerekse ilgili bölümlerde okutulan matematik eğitimi derslerinde öğretmen ve öğretmen adaylarının dikkati bu konuya çekilebilir. Ayrıca manipülatifler olarak isimlendirilen somut metaryaller, çocukların akıl yürütme ve matematiksel düşünme becerilerinin gelişiminde önemli bir yer tuttuğundan, öğretmen ve öğretmen adaylarına çocuklarla toplama ve çıkarmaya ilişkin sözel problem çalışmaları yaparken somut materyaller kullanmaları önerilebilir.

Bu çalışmanın sonuçları her ne kadar alanyazına önemli katkılar sağlasa da bazı sınırlılıklara sahiptir. Yapılan çalışma sadece okul öncesi öğretmenlerinin ve öğretmen adaylarının toplama ve çıkarmaya ilişkin sözel problem kurma becerileri ile sınırlıdır. Bir başka çalışmada sınıf öğretmenlerinin de sözel problem türlerine yönelik bilgi ve farkındalık düzeyleri incelenebilir. Ayrıca bu çalışmada sadece toplama ve çıkarmaya ilişkin sözel problemler incelenmiş olup gelecek çalışmalarda, eşit paylaştırmayı temel alan bölme işlemine ilişkin sözel problem türlerine de yer verilebilir. Ayrıca öğretmenlerin mesleki deneyimleri gibi bazı değiş̧kenler ele alınarak öğretmenlerin sözel problem kurma becerileri değişkenler açısından da incelenebilir. 


\section{Kaynakça}

Akman, B. (2002). Okul öncesi dönemde matematik. Hacettepe Üniversitesi Eğitim Fakültesi Dergisi, 23, 244-248.

Aktaş-Arnas, Y. (2012). Okul öncesi dönemde matematik eğitimi, Ankara: Vize Yayınevi.

Altun, M. 2000. Matematik öğretimi (8. Basım). Bursa: AlfaYayınları

Aunola, K., Leskinen, E., Lerkkanen, M. K., and Numi, J. E. (2001). Developmental dynamics of math performance from preschool to grade 2. Journal of Educational Psychology, 96(4), 699-713. doi: 10.1037/0022-0663.96.4.699

Baroody, A. J., Lai, M. L., and Mix, K. S. (2006). The development of young children's early number and operation sense and its implications for early childhood education. In B. Spodek and O. N. Saracho (Eds.), Handbook of research on the education of young children (2nd ed.) (pp. 187-221). Mahwah, NJ: Lawrence Erlbaum.

Büyüköztürk, Ş., Çakmak, E. K., Akgün, Ö. E., Karadeniz, Ş. ve Demirel, F. (2010). Bilimsel araştırma yöntemleri. Ankara: PegemA.

Copley, J. V. (2004). The early childhood collaborative: A professional development model to communicate and implement the standards. D. H. Clements, J. Sarama, and A. M. DiBiase (Eds.), Engaging young children in mathematics: Standards for early childhood mathematics education. (pp. 401-414). Mahwah, NJ: Lawrence Erlbaum.

Carpenter, T. P., Fennema, E., Peterson, P., Chiang. C., and Leaf, M. (1989). Using knowledge of children's mathematical thinking in classroom teaching: An experimental study. Amerium Educational Research Journal, 26, 499-531.

Clements, D. H., and Samara, J. (2013). Math in the early years: A strong predictor for later school success. The Progress of Education Reform, 14(5). 1-7. Retrieved from https://www.du.edu/kennedyinstitute/media/documents/mathin-the-early-years.pdf

d'Ailly, H. H., Simpson, J., and MacKinnon, G. E. (1997). Where should "you" go in a math compare problem? Journal of Educational Psychology, 89(3), 562-567.

Desli, D., and Loukidou, H. (2014). Addition and subtraction word problems in greek grade $a$ and grade $b$ mathematics textbooks: distribution and children's understanding. Retrieved from http://www.cimt.org.uk/journal/desli.pdf

Dinç-Artut, P. (2015). Preschool children's skills in solving mathematical word problems. Educational Research and Reviews, 10(18), 2539-2549. 
Duncan, G. J., Dowsett, C.J., Claessens, A., Magnuson, K. Huston, A. C., Klebanov, ... Japel, C. (2007). School readiness and later achievement. Developmental Psychology, 43(6), 1428-1446. doi: 10.1037/0012-1649.43.6.1428

Gelman, R., and Gallistel, C. R. (1978). The children's understanding of number. Cambridge, MA: Harvard University Press.

Gürgah-Oğul İ., and Aktaş-Arnas Y. (2016). Preschool children's mathematical experiences in outdoor play. In R. Efe, İ. Koleva, E. Atasoy, and İ. Cürebal, (Eds.), Developments in educational sciences (pp. 196-207). Sofia: St. Kliment Ohridski University Press.

Haylock, D., and Cockburn, A. (2004). Understanding mathematics in the lower primary years, London: Paul Chapman Publishing.

Hill, H. C., Rowan, B., and Ball, D. L. (2005). Effects of teachers' mathematical knowledge for teaching on student achievement. American Educational Research Journal, 42(2), 371-406.

Işık, C. ve Kar, T. (2011). İlköğretim 6, 7 ve 8. sınıf öğrencilerinin sayı algılama ve rutin olmayan problem çözme becerilerinin incelenmesi. Ahi Evran Üniversitesi Kırşehir Eğitim Fakültesi Dergisi, 12(1), 57-72.

İnel, D., Evrekli, E. ve Türkmen, L. (2011). Sınıf öğretmeni adaylarının problem çözme becerilerinin araştırılması. Pamukkale Üniversitesi Eğitim Fakültesi Dergisi, 29(1), 167-178.

Jordan, N. C., Kaplan, D., Locuniak, M. N., and Ramineni, C. (2007). Predicting firstgrade math achievement from developmental number sense trajectories. Learning Disabilities Research and Practice, 22(1), 36-46.

Jordan, N.C., Kaplan, D., Ramineni, C., and Locuniak, M. N. (2009). Early math matters: Kindergarten number competence and later mathematics outcomes. Dev Psychol. 45(3), 850-67. doi: 10.1037/a0014939

Kamii, C., Miyakawa, Y., and Kato, Y. (2004) The Development of logicomathematical knowledge in a block-building activity at ages 1-4, Journal of Research in Childhood Education, 19(1), 44-57.

Kayan, F. ve Çakıroğlu, E. (2008). İlköğretim matematik öğretmen adaylarının matematiksel problem çözmeye yönelik inançları. Hacettepe Üniversitesi Ĕ̆itim Fakültesi Dergisi, 35, 218-226.

Korkmaz, E. ve Gür, H. (2016). Öğretmen adaylarının problem kurma becerilerinin belirlenmesi. Balıkesir Üniversitesi Fen Bilimleri Enstitüsü Dergisi, 8(1), 64-74.

La Paro, K. M., and Pianta, R. C. (2000). Predicting children's competence in the early school years. A meta-analytic review. Review of Educational Research, 70, 443-484. 
Milli Eğitim Bakaknlığı (2013). Okul öncesi ĕgitim programı. Ankara: MEB.

Nunes, T., and Bryant, P. (2008). Çocuklar ve matematik: Matematik öğretiminde yeni adımlar [Children doing mathematics]. S. Koçak (Çev.). İstanbul: Doruk yayıncılık. (1996)

Olkun, S., and Toluk, Z. (2002). Textbooks, word problems and student success on addition and subtraction. International Journal for Mathematics Teaching and Learning. Retrieved from http://www.cimt.org.uk/journal/index.htm

Parmjit, S. (2006). An analysis of word problems in school mathematics texts: Operation of addition and subtraction. Journal of Science and Mathematics Education in S. E. Asia, 29(1), 41-61.

Parmjit, S., and Teoh, S. H. (2010). An analysis of addition and subtraction word problems in mathematics textbooks used in Malaysian primary school classrooms. Brunei Int. J. of Sci. \& Math. Edu., 2(1), 68-85.

Peterson, R., and Felton-Collins, V. (1986). The Piaget handbook for teachers and parents, New York, NY: Teachers College Press.

Peterson, P. L., Fennema, E., and Carpenter, T. P. (1989). Using knowledge of how students think about mathematics. Educational Leadership, 46(4), 42-46.

Resnick, L. B. (1989). Developing mathematical knowledge. American Psychologist, $44,162-169$.

Sarama, J., and Clements, H. D. (2009). Early childhood mathemetics education research. New York, NY and London: Routledge.

Sarıbaş, Ş., and Aktaş-Arnas, Y. (2016). Preschool children's verbal problem solving skills and the types of verbal problems that teachers present to children. Pegem Ĕgitim ve Ögretim Dergisi, 6(4), 549-568.

Sarıbaş, Ş. ve Aktaş-Arnas, Y. (2017). Okul öncesi dönemde öğretmenler ve eğitim materyalleri çocuklara hangi tür sözel problemleri sunuyor? Necatibey Eğitim Fakültesi Elektronik Fen ve Matematik Eğitimi Dergisi, 11(1), 81-100.

Schoenfeld, A. H. (1988). When good teaching leads to bad results: The disasters of "well-taught" mathematics courses. Educational Psychologist, 23(2), 145-166.

Seo, K. H., and Ginsburg, H. P. (2004). What is developmentally appropriate in early childhood mathematics education? Lessons from new research. In D. H. Clements, J. Sarama, and A. M. DiBiase (Eds.), Engaging young children in mathematics: Standards for early childhood mathematics education (pp. 91104). Hillsdale, NJ: Erlbaum.

Serin, O. (2010). Sınıf öğretmenlerinin problem çözme becerilerinin çeşitli değişkenler açısından incelenmesi. Eğitim ve Bilim, 31(142), 80-88.

Sperry-Smith, S. (2001). Early childhood mathematics. U.S.A.: Allyn and Bacon. 
Starkey, P. (1992). The early development of numerical reasoning. Cognition, 43(2), 93-126. doi: 10.1016/0010-0277(92)90034-F

Stern, E. (1993). What makes certain arithmetic word problems involving the comparison of sets so difficult for children? Journal of Educational Psychology, $85,7-23$.

Stevenson, H. W., and Newman, R. S. (1986). Long-term prediction of achievement and attitudes in mathematics and reading. Child Development, 57, 646-659.

Swars, S., Hart, L. C., Smith, S. Z., Smith, M. E., and Tolar, T. A. (2007). Longitudinal study of elementary pre-service teachers' mathematics beliefs and content knowledge. School Science and Mathematics, 107(9), 325-335.

Tarım, K. (2017). Problem solving levels of elementary school students on mathematical word problems and the distribution of these problems in textbooks, Çukurova Üniversitesi Ĕ̈itim Fakültesi Dergisi, 46(2), 639-648.

Tarım, K., ve Deretarla-Gül, E. (2003). Anasınıfı ve ilköğretim birinci sınıf öğrencilerinin toplama ve çıkarma becerilerinde kullandıkları stratejilerin incelenmesi. G. Haktanır ve T. Güler (Ed.), OMEP Dünya konsey toplantısı ve konferansı içinde (ss. 270-283). Kuşadası.

Tertemiz, N. I., ve Sulak, S. E. (2013). İlköğretim beşinci sınıf öğrencilerinin problem kurma becerilerinin incelenmesi. İlkögretim Online, 12(3), 713-729.

Thompson, A. G. (1984). The relationship of teachers' conceptions of mathematics and mathematics teaching to instructional practice. Educational Studies in Mathematics, 15(2), 105-127.

The National Council of Teachers of Mathematics (2000). Principles and standards for school mathematics. Retrieved from https://www.nctm.org/standards/

Ulu, M. (2008). Sinıf öğretmeni, sinıf öğretmeni adayı ve 5. sinıf öğrencilerinin dört işlem problemlerini çözmede kullandıkları stratejilerin karşılaştırılması (Yayımlanmamış yüksek lisans tezi). Kocatepe Üniversitesi Sosyal Bilimler Enstitüsü, Afyon.

Umay, A. (2003). Matematiksel muhakeme yeteneği. Hacettepe Üniversitesi Ĕ̌gitim Fakültesi Dergisi, 24, 234-243.

Van De Walle, J. A. (1994). Elementary school mathematics. Virginia: Longman.

Van De Walle, J. A., Karp, K. S., and Bay-Williams, J. M. (2016). Elementary and middle school mathematics: teaching developmentally (7th edition). New York, NY: Addison Wesley Longman. 


\section{Preschool Teachers and Preservice Teachers' Verbal Problem Posing Skills Related to Addition and Subtraction $^{1}$}

\begin{tabular}{cccc}
\hline ARTICLE TYPE & Received Date & Accepted Date & Published Date \\
Research Article & 02.18 .2019 & 10.25 .2019 & 04.01 .2020 \\
\hline Yaşare Aktaş Arnas iD & ${ }^{2}$ and Kamuran Tarım iD & \\
& Çukurova University
\end{tabular}

\section{Abstract}

The aim of this study is to examine preschool teachers' and pre-service teachers' verbal problem-posing skills. The data of the study was gathered from 179 third and fourth year students studying in the preschool teaching department in a public university in Adana in the 2016-2017 academic year and 93 preschool teachers working in pre-school education institutions affiliated to Provincial Directorate of National Education in Adana. The data of the study was collected by using Verbal Problem Posing Form created by the researchers. Frequency and percentage techniques were used to analyze the data. As a result of the study, it was seen that teachers and pre-service teachers were able to pose some verbal problem types correctly while they could not pose other types. A majority of both teachers and pre-service teachers were largely successful in posing joining / result unknown; joining / change unknown; separating / result unknown and separating / change unknown problem types. Furthermore, both teachers and pre-service teachers had very little success in posing part-part-whole / whole unknown; part-part-whole / part unknown; comparison / smaller unknown; comparison / difference unknown problem types. Additionally, a majority of participants were found to be unsuccessful in posing the comparison/larger unknown type of problems.

Keywords: Mathematics education, preschool education, preschool teacher, pre-service teacher, problem posing, verbal problems.

${ }^{1}$ This artcile is supported by Çukurova University Department of Scientific Research Projects (No: SBA 2018 10333)

${ }^{2}$ Corresponding Author: Prof. Dr., Education Faculty, Department of Primary Education, Early Childhood Education, E-mail: yasare@cu.edu.tr, https://orcid.org/0000-0002-0738-9325

${ }^{3}$ Prof. Dr., Education Faculty, Mathematics and Science Educ. Dept., Mathematics Education, E-mail: gkamuran@cu.edu.tr, https://orcid.org/0000-0002-2048-5207 


\section{Purpose and Significance}

Addition and subtraction operations are two of the basic mathematical skills that children should also be taught in pre-school education. It is crucial for children to work with word problems in the pre-school period to understand addition and subtraction operations (Tarım and Deretarla-Gül, 2003). The most significant part of mathematical programmes is the children's solving word problems relating to addition and subtraction. In addition, the skill of solving word problems is not developed in several weeks or months. The development of this skill requires a slow and continuous procedure (Van de Walle, 1994). Therefore, it is recommended to include learning and teaching activities that are oriented at these skills starting from the pre-school period in order to develop the children's skills of solving word problems (Tarım, 2017; Van De Walle, Karp and Bay-Williams, 2016). It cannot be ignored that both pedagogical and subject matter knowledge of the teachers and pre-service teachers who are the implementers of these activities are important. In other words, the subject matter knowledge of the teachers about word problems and the sufficiency of their pedagogical knowledge about carrying these into the teaching and learning environment are important.

In this context, the purpose of this study is to investigate the skills of pre-school teachers and pre-service teachers about forming word problems related with addition and subtraction. For this purpose, the following research questions were formulated:

1. What are the kinds of word problems which the pre-school teachers and preservice teachers pose about addition and subtraction?

2. What is the appropriateness of the types of word problems that the pre-school teachers and pre-service teachers form about addition and subtraction, the language they use while forming the problem and the concepts that are used in the problem for the children in the pre-school period?

\section{Method}

In this division, information is given about the participants, data collection tools, data collection process and data analysis.

Participants.This study consists of two different groups. One of these is preschool teachers and the other one is pre-service pre-school teachers. The first sample group of the research consists of 93 volunteer pre-school teachers working at 41 independent pre-schools of Provincial Directorate of National Education in the central districts of Adana.

Data collection tools. The Form of Posing Word Problems, which was developed by the researchers, was used in this study as the data collection tool so as to determine the teachers' and pre-service teachers' skills of posing word problems. 3 questions about addition and 3 questions about subtraction (6 in total) including numerical symbols, were asked for the participants in the form. The teachers were instructed to convert these symbolical questions into the word problems about 
addition and subtraction. Through this procedure, the teachers were supposed to pose word problems in type of joining, separating, part-part-whole and comparison under 11 sub-categories.

Data analysis. The teachers converted the symbolical operations about addition and subtraction in the Form of Posing Word Problems into the word problems. Then the problems which were posed by the teachers were analysed one by one by grounding on four word problem types and 11 sub-categories. Each word problem that the teachers posed was considered as successful if it was correct and as unsuccessful if it was incorrect. 1 point was given for each correct answer of the teachers and the total points from the correct answers were calculated. In the study, frequency and percentage values about the word problems which the pre-service teachers posed about addition and subtraction were calculated.

\section{Results}

The types of the word problems that the teachers and pre-service teacher posed about addition and subtraction were analysed and it was determined that the teachers were more successful at Result unknown (94.6\%) and Change unknown (84.9\%) join word problems while they were less successful at Start unknown (49.5\%) join word problems. Besides, it was also observed that a majority of the teachers were successful at posing Result unknown (96.8\%), Change unknown (87.1\%) and Start unknown $(79.6 \%)$ seperate word problems. On the other hand, it was revealed that only a few of the teachers were successful at posing Whole unknown $(6.5 \%)$ and Part unknown $(10.7 \%)$ Part-part-whole problems. Unfortunately, none of the teachers was successful at posing Difference unknown and Unknown big quantity comparison word problems. Only one of the teachers succeeded in posing Unknown small quantity comparison word problem.

The analysis of the results presented that a great part of the pre-service teachers was successful at Joining / Result unknown (83.2\%), Joining / Change unknown (79.3 $\%)$, Separating / Result unknown (92.2\%), Separating / Change unknown (85.5\%) and Separating / Start unknown $(79.3 \%)$ word problem types. It was also seen that some part of the pre-service teachers could pose Joining / Start unknown (38\%), PartPart-whole / Whole unknown (12.3\%), Part-part-whole / Part unknown (6.1\%) word problems; however, they could not pose Comparison / Unknown big quantity and Comparison / Unknown small quantity while only one pre-service teacher could pose Comparison / Difference unknown $(0.6 \%)$ word problem.

It was also analysed whether the word problem types which were posed by the teachers and pre-service teachers about addition and subtraction were appropriate for the development levels of the pre-school students. The results of the analysis showed that a great majority of the word problems posed by the teachers was appropriate for the development level of the pre-school students $(89.2 \%)$. It was determined that more than one-third of the teachers $(34.7 \%)$ referred to the child in the word problems by using you language. Moreover, most of the concepts and words which were used 
within the word problems were concrete $(96.2 \%)$ and only a few of the word problems $(1.6 \%)$ contained abstract concepts and words.

It was found that a great majority of the word problems $(85.5 \%)$ posed by the pre-service teachers was appropriate for the development levels of the pre-school students. It was observed that less than one-third of the pre-service teachers $(28.4 \%)$ preferred using you language in the word problems which they posed. Another remarkable point in the word problems posed by the pre-service teachers was that most of the concepts and words in the problems $(91.5 \%)$ were concrete while very few of the word problems (6.6\%) contained abstract concepts and words.

\section{Discussion and Conclusions}

It was determined in this study, which evaluated the pre-school teachers' and pre-service teachers' skills of posing word problems in general, that the pre-school teachers and pre-service teachers were more successful at posing result unknown, change unknown and start unknown word problems in the type joining and separating while they were not successful at posing problems in the type of part-part-whole and comparison. There are similar findings in the related literature both in Turkey and abroad. For example, Sarıbaş and Aktaş-Arnas (2017) conducted a study with 325 pre-school teachers and they concluded that the word problems which were presented the most by the pre-school teachers were result unknown (in the type of joining and separating problems) and part unknown (in the type of part-part-whole problems) problems types about addition and subtraction for the students. It was also determined that the word problems which were presented the least were start unknown and change unknown problems in the type of joining and separating problems; whole unknown problems in the type of part-part-whole problems and unknown big and small quantity problems in the type of comparison problems. In another study by Sarıbaş and AktaşArnas (2016), it was found out in the one on one interviews that the teachers who participated in the research expressed that they used word problems with result unknown more in addition and subtraction operations. It was presented in the related study that the teachers admitted not having enough knowledge about the types of word problems and they did not present some types of problems as all types of word problems were not included in the written materials that were used in pre-school education. These obtained results also show similarities with the results of the studies conducted abroad (Nunes and Bryant, trans. 2008; Carpenter Fennema, Peterson, Chiang and Leaf, 1989). These studies revealed that the teachers presented result unknown problem types mostly to children, too. This result showed that the teachers and pre-service teachers did not have enough knowledge about the types of word problems about addition and subtraction and their awareness levels were low. One of the basic reasons for this is the teachers' and pre-service teachers' experiencing the word problem types the solutions of which were generally single-stage during their own educational lives. Another reason of this is the general use of result unknown problems in mathematics activity books (Desli and Loukidou, 2014; Parmjit, 2006; 
Parmjit and Teoh, 2010; Sarıbaş and Aktaş-Arnas, 2017). The teachers and preservice teachers meet with the same types of problems all the time.

The criteria which the pre-school teachers and pre-service teachers paid attention while posing the word problems were analysed and it was seen that a great majority of the pre-school teachers and pre-service teachers posed problems appropriate for the development levels of pre-school children and they included concrete concepts and words while posing the problems.

In this research, it was concluded that a great majority of the pre-school teachers and pre-service teachers posed word problems that were appropriate for the development level of the pre-school children. This might be closely related to the courses about both child development and pedagogy which they took during their educational process. It can be said that the courses that the pre-service teachers took and the practices that they made during their educational process improved their knowledge and skills about this issue.This result shows similarities with the findings of Sarıbaş and Aktaş-Arnas's (2017) study which focused on the word problems that the pre-school teachers presented to the children. In that study, the teachers mostly emphasized that the word problems had to be chosen appropriately according to the development levels of the children.

In this study, it was ascertained that a great majority of the teachers and preservice teachers not only posed word problems appropriate for the development levels of the children but also used concrete concepts and words in those problems. It is also stated in the related literature that mathematical knowledge and thoughts should be explored by concrete and real experiences before they are approached in an abstract way because of the developmental characteristics of the children in the pre-school period (Akman, 2002; Aktaş-Arnas, 2012; Peterson and Felton-Collins, 1986).

Furthermore, it was determined in this study that one-third of the teachers and pre-service teachers used personal pronouns (you language) while posing the word problems. It was emphasized in the related literature that the language structure which is used in the presentation of the word problems to the children is substantial and the children become more successful when you language (personal pronouns) is preferred in the word problems. For example, Dinç-Artut (2015) conducted a study with the children in the age group of 5-6. In the study, the word problems were first presented to the children in their original forms. Then, the problems were rewritten with you language by referring to the child himself if the children were not successful. It was concluded in the research that the success of the children increased by $8 \%$. d'Ailly, Simpson and MacKinnon (1997) carried out a study with the children at the $3^{\text {rd }}, 4^{\text {th }}$ and $5^{\text {th }}$ grades and determined that the children's performances enhanced when the problems were presented in you language by referring the children themselves. They also found that using the you language lightened the load of the working memory (short-term memory) of the students by facilitating the coding process in the word problems. 
The obtained results showed that the awareness levels of the teachers and preservice teachers about the types of word problems were not at sufficient level. In this sense, the teachers and pre-service teachers need to improve their knowledge and competences about the types of word problems. In the teacher training and education programmes, the teachers' awareness about the word problems in mathematics should be increased and the teachers have to gain fundamental skills. A similar study can be conducted with pre-school teachers in in-service teaching. Upon the determination of deficiencies, in-service trainings can be given to pre-school teachers. 